\title{
Criminal Law In Antarctica: Law West Of The Pecos Revisited
}

W. Michael Seganish, (Email: wseganish@aol.com), Towson University

\begin{abstract}
In a criminal law matter, jurisdiction is often a minor consideration. That is, where the crime is committed determines who has the right to prosecute and what law applies. There may be some jurisdictional issues whether state law or federal law governs in the United States; but this is by and large resolved by one taking jurisdiction. The same would be normally true in the international law area where it was committed. That is, if a crime is committed in France or Germany, then the law where it was committed would prevail subject to other international issues such as diplomatic immunity which would prevent a sovereign from prosecuting. This is not the case in Antarctica because Antarctica belongs to no one particular nation. It is governed by the Antarctic Treaty. The Treaty is mindful of territorial claims and defers to a sector theory as to which criminal law applies. This means in this sovereign-less continent that one cannot tell specifically what criminal law, if any, exists to regulate activities. This has numerous ramifications other than the micro application in one particular case because from a macro point of view actions can occur for which there is no remedy. The analysis limits itself to criminal law issues, but much larger implications exist in the event of an environmental disaster, for example, where there may be no remedy against an offending party.
\end{abstract}

\subsection{Introduction}

A ntarctica, the "world's last sovereign less continent", faces increasing legal uncertainty as the continent's population continues to grow in the absence of a specific body of law governing criminal actions. Int'l L. Rev. 667 (1994). This situation is not dissimilar from the American west in the 1800's, The Law West of the Pecos where "the Judge was the Law" and the "Judge" determined what the law was at a particular moment instead of using a "stare decisis" approach. That is, under the latter approach past cases are used as a guide of what future case outcomes should be and not based on the whim of a judicial officer hearing the case. An even larger problem is that one cannot be sure if one is committing a criminal act. Presently, this continent is not governed by any one nation's set of laws: rather it has been controlled by a group of member nations under the "Antarctic Treaty". The problem which this causes may be succinctly stated: One cannot be sure what constitutes criminal activity; what country has jurisdiction to punish and what is the punishment, if any should/will be.

To analyze this problem is a two step process. One must first determine who has the right to generally regulate i.e., promulgate and enforce laws in Antarctica. Second, one must examine the various competing jurisdictional bases which exist in criminal matters to ascertain which potential law(s) can be applied. This paper will examine these issues and attempt to assist the reader to understand the dilemma presented and see if a solution is feasible.

Readers with comments or questions are encouraged to contact the author via email.

\subsection{Pre-Antarctic Treaty}


Antarctic belongs to no particular nation. Nine countries, all members of the Antarctic Treaty, have asserted Territorial Sovereignty over parts of Antarctica: For example, seven countries: Argentina, Chile, France, New Zealand, Norway and the United Kingdom assert territorial sovereignty over pie shaped sectors. ${ }^{\text {iii }}$ Additionally, the United States and Russia claim the right to make territorial claim over the entire continent if they chose to do so. ${ }^{\text {iv }}$

Before the Treaty was established in 1959, nine countries had asserted and exercised their claims in/on Antarctica. In order to maintain peace among all contracting Parties of the Treaty, to be discussed in the next section, Article IV was written to protect the rights which had already been asserted by the above countries. However, the Treaty does not deny any new claim or enlargement of an existing claim of territorial sovereignty in Antarctica while the Treaty is in force. The importance of Article IV is that it allows the countries who asserted claims before the treaty was in force to continue to exercise territorial jurisdiction over their claimed sectors although it does not give it any formal legal jurisdiction. This means that a country has jurisdiction over a territory by virtue of the exercise of a claim and that this provides jurisdiction to regulate conduct and to determine what is prohibited criminal activity in the area of its territorial claim. It is not mandatory, however, that a country exercise jurisdiction in a particular case. This is in contrast to criminal law enforcement in the United States which generally consists of a joint effort of police, prosecutors and court systems, to enforce criminal law both common law and statutory in nature. In Antarctica, there exists multiple sets of rules depending upon where the act occurs and whether the country which has jurisdiction decides to assert its right to prosecute such activity.

\subsection{The Antarctic Treaty: A Source Of Scientific Cooperation}

The Antarctic Treaty, established primarily for the purpose of effectuating a means by which all nations could have use of this continent for scientific research, provides for the role of its member nations as the governing authority.

Since the inception of the Antarctic Treaty, the number of member nations has evolved from the initial group of twelve (Argentina, Australia, Belgium, Chile, France, Japan, New Zealand, Norway, South Africa, Russia, the United Kingdom, and the United States) to the current number of thirty-nine. ${ }^{v}$ Among these member nations, a governing committee of nations called the Antarctic Treaty Consultative Party, functions as the continuing "authoritative nucleus for overseeing Antarctic Activities.", Currently, twenty-two nations belong to this governing party. This "nucleus" does not currently act as a legislative body for the promulgation of comprehensive criminal statutes. Obviously this general right to oversee by these nations has not been exercised as a right to regulate criminal activity.

Since there is no legislative body and countries have territorial claims, one must ascertain the source of a particular country's power to regulate criminal activities. While the Antarctic Treaty does not officially recognize claims by any nation, it does not infringe upon rights which have been previously asserted:

"Nothing contained in the present Treaty shall be interpreted as:

1. a renunciation by any contracting party of

previously asserted rights of or claims to be territorial

sovereignty in Antarctica.

3. ......Prejudicing the position of any contracting party as regards its

recognition or non-recognition of any other state's rights of or claim or

basis of claim to territorial sovereignty in Antarctic. (Article IV.)"vii

\subsection{Individual Jurisdiction: Territorial Based}

One must determine the source of the ability to exercise jurisdiction over criminal matters in Antarctica. Prior to the enactment of the Antarctic Treaty, seven countries had claimed territorial rights to various areas of Antarctic, based on "state succession...discovery...[or] the so-called 'sector theory". viii It was the United States who recognized the inherent problems with this arrangement and which proposed a unified agreement for the peaceful 
occupation of the continent. ${ }^{\text {ix }}$ The impetus behind the drafting of the Treaty was the desire to establish Antarctica as a source of "scientific investigation", (and not primarily criminal regulation), whereby all nations could utilize the natural resources of the continent in "accordance with the interests of science and the progress of all mankind. ${ }^{\mathrm{x}}$ Under the terms of the Treaty, informal guidelines were established for international cooperation in maintaining the continent as a peaceful, research-based community. However, it is interesting to note that the Treaty "neither recognized nor refuted old territorial claims on the continent", which may lead to confusion over other issues in the future. ${ }^{\mathrm{xi}}$

At the time the Treaty was drafted in 1959, the population of Antarctica consisted primarily of scientific

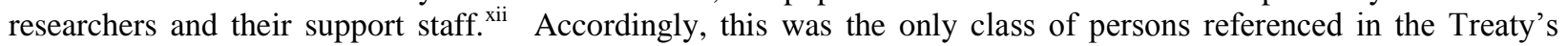
choice of law provision. These persons typically are not a "criminal element" in need of any close scrutiny. While the Treaty did not specifically address the issue of criminal sanctions, it did state that 'observers', scientists and other expedition members were subject to the law of their citizen country "in respect of all acts or omissions occurring" during the course of their expedition. However, as was mentioned earlier, the countries are not forced to exercise jurisdiction in any particular case and there exists no "police force"per se to enforce these regulations. What this means as a practical matter is that criminal jurisdiction over a criminal act is still usually exercised on a territorial basis. ${ }^{\text {xiii }}$ Notwithstanding this lack of specific criminal law in the Treaty, it should be noted that Antarctica has yet to experience a serious crime problem, despite the "absence of agreed rules of jurisdiction.,"xiv

\subsection{Individual Jurisdiction: Nationality Based}

In addition or alternatively there exists nationality-based jurisdiction as a basis for regulation of criminal activity apart from the Treaty. This means the country of which a person is a citizen can prosecute a person for illegal conduct which occurs outside the boundaries of that country. This can be enforced if the location in which the criminal activity has occurred does not exercise their territorial jurisdiction. Again, it is difficult to envision how this can be uniformly (regularly) done without a police enforcement arm of government.

For the above reasons, criminal jurisdiction in Antarctica is usually exercised on a territorial basis. When a person commits a crime in a particular country's territorial sector or a scientific research base, that country has criminal jurisdiction over the alleged offender. Scientific research bases, regardless of their territorial location, are considered part of the state possessing the scientific research base's jurisdiction. If that country chooses not to exercise their jurisdiction, then nationality-based jurisdiction can be enforced. If this seems quite perplexing, it is. In the United States there are sometimes jurisdictional disputes. For example, Federal jurisdiction rather than state jurisdiction exists in the crime of bank robbery because of the Federal Deposit Insurance coverage.. However, these rules are understandable; but with the territorial claims and differing nationalities, the combinations and permutations of potential criminal laws which could be applicable in Antarctica is staggering.

\subsection{Exception To Nationality Based Jurisdiction}

To make matters worst, nationality-based jurisdiction does not apply to all persons in Antarctica, because some people born in Antarctica do not have an official nationality. Therefore, only territorial based jurisdiction can be enforced. In the situation when a child is born in Antarctica and he/she commits a crime as a minor (below age 18), then either nationality-based jurisdiction or territorial jurisdiction would be enforced. This depends primarily on whether the country's basis for nationality is jus sanguinis or jus soli. Jus Sanguinis, "law of the blood", is nationality based on the nationality of the parents. Jus Soli, "law of the soil", is nationality based on the country or place of birth. If the country bases their nationality on jus sanguinis, which the majority of countries do, the minor would be under the criminal code of the country in which his/her parents are legal citizens. Whereas if the country bases their nationality on jus soli only, territorial based jurisdiction is enforced upon the minor, because legally the minor has no official nationality. Territorial based jurisdiction can result in many problems when certain countries do not recognize the territorial sovereignty of a country's sector or their territories overlap. The United States, for example, does not recognize any country's criminal jurisdiction based on territorial sovereignty. Thus the United States retains the right to have criminal jurisdiction over crimes committed by United States citizens in Antarctica or crimes committed by non-U.S. citizens who are with a United States expedition and who commit crimes against 
United States citizen or property. With respect to the latter, the United States generally refrains from prosecution of the accused if the country of the accused decides to exercise their nationality based jurisdiction before the criminal trial has begun.

\subsection{Conflict Of Law: Two Nations Claiming Jurisdiction}

This presents another problem: What does one do if two countries claim jurisdiction over an act. If a dispute arises between contracting parties to the Antarctic Treaty with regards to jurisdiction, then they "shall immediately consult together with a view to reaching a mutually acceptable solution." " is not illegal in the country which has asserted a territorial claim to a sector but it is illegal in the person's country and this could result in criminal prosecution. There are cases where a homicide was committed (a situation where a person was beaten to death with a hammer) but there no prosecution resulted because the act was not illegal because of the absence of an applicable law making it so. Further compounding this problem is the requirement that parties "shall immediately" consult...to reach a mutually acceptable solution" in conflict of law situation. This might be a workable doctrine in a civil dispute, i.e., monetary claims to sit down and discuss the law to be applied; It is difficult to envision this approach working in a criminal matter where a person's freedom is at stake and one cannot be certain if his action is a crime or not until after the fact. Further, societal interests may dictate a violent offender's removal to protect the rest of the public but until the parties meet and reach a solution no sanctions can be taken.

\subsection{Necessity For Change}

Antarctica has remained relatively free from criminal activity, with the few, mainly drug related offenses being subject to the "national law of the expedition." xvi However, faced with the increasing population expansion in Antarctica, particularly from the non-scientific community and the tourist industry, Antarctic Treaty member nations will need to confront the jurisdictional dilemma soon if Antarctica is expected to remain a peaceful, regulated international community.

This absence of settled law in criminal matters must be dealt with in the immediate future, as the continent's population grows significantly larger every year. Historically, the small number of inhabitants resulted in relatively few criminal infractions and perhaps many of these never reported because of distance and weather conditions and the lack of prosecutorial resources, e.g., investigations, police, etc. As of 1990, twenty-seven countries maintained winter bases in Antarctica, with an additional influx of two thousand people residing in Antarctica during the summer months. Compounding this problem is the fact that this entire population is concentrated in an area of the continent that is comparable in size to the state of Illinois. ${ }^{\text {xvii }}$

Disputes over old jurisdictional boundaries at the time the Treaty was drafted prevented the enactment of a more comprehensive provision for enforcing local control. ${ }^{\text {viii }}$ That is, the Treaty sought to avoid disturbing claims which had previously been asserted. In large part, this oversight reflected the drafters' inability to anticipate the amount of interest that the continent would gather among the non-scientific community, and the ensuing population growth. The fact that the drafters failed to anticipate the attractiveness of Antarctica to members of the nonscientific population is reflected in the Treaty's failure to include any provision establishing a jurisdictional basis for visiting persons who were not citizens of a member nation. ${ }^{\text {xix }}$ Currently, people visiting the continent on a nonscientific basis are not subject to abide by the laws of any particular nation. Rather, the Treaty directs that representatives of parties of non-member nations "shall immediately consult together with a view to reaching a mutually acceptable solution" in the event of a dispute. ${ }^{\mathrm{xx}}$ The Consultative Party should develop a body of law to resolve this issue in accordance with the Treaty's original mandate to "develop an adequate jurisdictional system.". xxi

\subsection{Conclusion}


If a comprehensive approach to adopt a more unified criminal code does not occur, the result could be disastrous. That is, one cannot know or sure which what law should be applied to the case. With the different countries involved; the territorial claims and nationality based jurisdiction, one cannot determine what is or is not a criminal act. If a comprehensive approach to adopt a unified criminal code does not occur, we are back to "the law west of the Pecos" as in the 1800's United States. That is, a Judge made it up as he/she went along and in Antarctica the Judge could pick virtually any law to apply. One cannot easily determine whether an action is a criminal act because of the various countries involved and multiple bases for jurisdiction. This is an intolerable situation for a criminal defendant and violates any reasonable concept of due process.

The solution here is more problematic. As a theoretical construct the Antarctic Treaty Consultative Party should take the lead and propose a unified criminal code. Hopefully, this rule of reason approach could be adopted; however, this will, in all likelihood, be viewed as an invasion of territorial sovereignty and will present a difficult change to effectuate despite the obvious need for greater uniformity and predictability in criminal matters.

\section{Endnotes}

${ }^{\mathrm{i} J o n a t h a n ~ B l u m, ~ T h e ~ D e e p ~ F r e e z e: ~ T o r t s, ~ C h o i c e ~ o f ~ L a w, ~ a n d ~ t h e ~ A n t a r c t i c ~ R e g i m e, ~} 8$ Emory

ii The Antarctic Treaty, Article IV, December 1, 1959, 1961 U.N.T.S. 72.

iii Id.

${ }^{\text {iv } I d . ~}$

${ }^{\mathrm{v}}$ Christopher J. Joyner, Book Review, 83 A.J.I.L. 605 (1989).

${ }^{v i}$ Antarctic Treaty, Article IV, December 1, 1959, 1961 U.N.T.S. 72.

vii Id.

viii Jonathan Blum, The Deep Freeze: Torts, Choice of Law, and the Antarctic Treaty Regime, 8 Emory Int'l L. Rev. $667,670$.

${ }^{\text {ix }}$ Id. At 671 .

${ }^{\mathrm{x}}$ The Antarctic Treaty, Dec. 1, 1959, 1961 U.N.T.S. 72.

${ }^{x i}$ Jonathan Blum, The Deed Freeze: Torts, Choice of Law, and the Antarctic Legal Regime, 8 Emory Int'1 L. Rev. 667 , at 673.

xii Id. At 675 .

xiii Id.

${ }^{x i v}$ Howard Taubenfeld et al.The Future of the Antarctic Regime: New Directions, 85 Am. Soc'y Int'1 L. Proc. 461, 472 (1991)

${ }^{\mathrm{xv}}$ The Antarctic Treaty, Article III, December 1, 1961 U.N.T.S. 2.

${ }^{x v i}$ Howard Taubenfeld et al., The Future of the Antarctic Regime: New Directions, 85 Am. Soc'y Int'1 L. Proc. 461, at 473.

xvii Id. At 473.

xviii Jonathan Blum, The Deep Freeze: Torts, Choice of Law, and the Antarctic Regime, 8 Emory Int'l L. Rev. at 675.

xix Id. At 676.

${ }^{x x}$ The Antarctic Treaty, Dec. 1, 1959, 1961 U.N.T.S. 72, at 80.

${ }^{x x i}$ Jonathan Blum, The Deep Freeze: Torts, Choice of Law, and the Antarctic Regime, 8 Emory Int'1 L. Rev. 667. 